16. Zagorulko A. M., Zagorulko O. Ye. Hnuchkyi plivkovyi rezystyvnyi elektronahrivach vyprominiuiuchoho typu: Pat. No. 108041 UA. MPK H05B 3/36, B01D 1/22, G05D 23/19. No. u201600827; declareted: 02.02.2016; published: 24.06.2016, Bul. No. 12. URL: http://uapatents.com/5-108041-gnuchkijj-plivkovijj-rezistivnijj-elektronagrivach-viprominyuyuchogo-tipu.html

17. Zagorulko O. Ye., Zagorulko A. M., Filonenko A. O. Method of manufacture of fruit-fresh paste: Pat. No. 119164 UA. MPK A23L 21/10. No. u201703852; declareted: 19.04.2017; published: 11.09.2017, Bul. No. 17. URL: http://base.uipv.org/searchINV/search. php?action= viewdetails\&IdClaim $=239139$

18. Zagorulko A. M., Kiptela L. V., Zagorulko O. Ye. Method of determining the strength of the multicomponent structure of plant pastes: Pat. No. 103094 UA. MPK (2015.01) A23B 7/00. No. u201413136; declareted: 08.12.2014; published: 10.12.2015, Bul. No. 23. URL: http://base.uipv.org/searchINV/search.php?action=viewdetails\&IdClaim=218265

\begin{abstract}
Охарактеризовано харчові плівки на основі полісахаридів. Досліджено наступні характеристики даних плівок: паропроникність, механічну мічність на розрив та прокол, вязкість плівкоутворюючого розчину. 3 иією метою в якості плівкоутворюючого матеріалу було застосовано ефір целюлози, карбоксиметилцелюлоза. Відповідно в якості розчинника використовувались дистильована вода, а в якості пластифікаторів глічерин, сорбіт та пропіленгліколь

Ключові слова: плівкоутворюючі покриття, пластифікатор, термін зберігання м'яса, синергізм, альгінат натрію, гідроколоїди
\end{abstract}

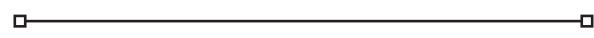

Охарактеризованы пищевые пленки на основе полисахаридов. Исследованы следующие характеристики этих пленок: паропроницаемость, механическая прочность на разрыв и прокол, вязкость пленкообразующего раствора. С этой целью в качестве пленкообразующего материала был применен эфир целлюлозы, карбоксиметилцеллюлоза. Соответственно в качестве растворитиля использовались дистиллированная вода, а в качестве пластификаторов - глицерин, сорбит и пропиленгликоль

Ключевые слова: пленкообразующие покрытия, пластификатор, срок хранения мяса, синергизм, альгинат натрия, гидроколлоиды

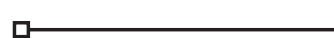

UDC 621.798.185-021.465:66.063.72:001.891 DOI: $10.15587 / 1729-4061.2018 .126369$

\section{EFFECT OF PLASTICIZERS ON THE QUALITATIVE INDICATORS OF FILM- FORMING COATINGS FOR THE PROTECTION OF CHILLED MEAT}

\author{
A. Kyshenia \\ $\mathrm{PhD}$ \\ Department of meat, fish and seafood technology* \\ E-mail: andrii.kyshenia@gmail.com \\ L. Vin n i ova \\ Doctor of Technical Sciences, Professor \\ Department of meat, fish and seafood technology* \\ Y. Kotliar \\ $\mathrm{PhD}$ \\ Department of technology of milk, \\ fats and perfume and kosmetycheskyh funds* \\ E-mail: yevhenii11@ukr.net \\ T. Volovik \\ PhD \\ Department of biochemistry, microbiology and \\ physiology of nutrition* \\ E-mail: tavol0929@gmail.com \\ K. Gar baz hi y \\ $\mathrm{PhD}$, Associate professor \\ Department of Security, Expertise and Commodity Research* \\ E-mail: garbazhiykat@gmail.com \\ *Odessa National Academy of Food Technologies \\ Kanatna str., 112, Odessa, Ukraine, 65039
}

\section{Introduction}

Continuous quality assurance and safety of products (chilled meat and meat products) is a top priority for specialists in the meat industry. Fresh meat has a very limited shelf life, which creates difficulties for manufacturers and poses a potential threat to consumers. Given this, selling meat products is geographically restricted by the place of production while transportation and storage requires special conditions.

In the process of storage and processing meat can be subjected to various types of damage: tanning, mucus forming, mold, rotting, change in color. The specificity of storing meat in semi-carcasses is the fact that not so many protection techniques are applicable. Given a complex geometric shape of a semi-carcass, the use of traditional packaging means 
will be ineffective. In addition, modern packaging, made of synthetic polymeric materials, not only increases the cost of food products, but also leads to the deterioration of environmental situation. In this regard, it is necessary to emphasize the development and extension of the range of packaging materials, manufactured based on organic substances (hydrocolloids), which do not pollute the environment and enable efficient protection of semi-carcasses during storage and transportation.

The disadvantage of film-forming coatings created only from hydrocolloids is the low values of mechanical indicators. In order to control mechanical properties, plasticizers of different origin are added to the composition of film-forming coatings. Given this, it is an important direction in the development of the industry to design, and conduct theoretical and experimental research into, natural coatings.

\section{Literature review and problem statement}

Food coatings are associated with a unique category of packaging materials that differ from the usual packing materials in that they can be consumed together with a packaged product. Food films and coatings are derived from biological materials, such as polysaccharides, proteins, lipids. Films and coatings act as a barrier (that prevents the effect of moisture, gases, light), they protect the product and prolong its shelf life [1].

Polysaccharides, proteins, lipids are basic components of food film-forming coatings. Composition of food coatings is determined depending on the desired properties of the film [2].

Alginates, along with other hydrocolloids, are a quite suitable material that can be used to protect products, specifically as a film-forming material. They are hygienic and environmentally safe, in addition, they have the capability to bind and remove heavy metals, radionuclides, and certain toxic substances from human body, clean the digestive system, which is also their positive characteristic. Thus, authors of paper [3] designed a film-forming coating based on sodium alginate and carboxymethyl cellulose (CMC).

When film-forming coatings are applied, two groups of forces act: between film-forming polymer molecules (cohesion), and between the coating and the product (adhesion). The degree of adhesion affects such properties of a film-forming coating as resistance, elasticity, permeability, etc. The strength of adhesion depends on the structure and chemistry of biopolymers, the fabrication procedure, parameters, the presence of plasticizers [4].

Each film-forming material is employed for the creation of a film with different barrier and mechanical properties. Requirements to the packaging of products define whether coatings are to be formed by the combination of film-forming materials, or by introducing certain additives, for example, plasticizers and emulsifying agents [5].

Polymers on a biological base are a fully recyclable material that completely biodegrades over a rather short time. The application of these polymers will make it possible to reduce the amount of plastic packaging with a short life cycle [6].

The effectiveness of hydrocolloid action is determined by the structural patterns of molecules (length of the chain, degree of branching, the presence of glycoside bonds, etc.) [7].
The dissolution and dispersion of hydrocolloids are affected by the size and shape of particles, specific surface, granulometric composition [8].

When utilizing hydrocolloids in the food industry, important is the degree of polymerization and substitution. An increase in the degree of polymerization predetermines an increase in the viscosity of a hydrocolloid in solution, and in the degree of substitution - enables the rapid hydration of hydrocolloids by increasing the possibility for water molecules to associate with it [9].

Structural and barrier properties of food films depend on certain parameters, such as the viscosity of a film-forming solution, the procedure of film-formation, thickness, water-vapor sorption characteristics, etc. Viscosity of the film-forming materials is of major importance in order to control properties of the film. Several researchers have shown the importance of behavior of the flow of dispersion films based on starch with the characteristics of dispersion exerting a significant impact on the smoothness of the surface and the physical appearance of a coating [10].

The quality of a coating in the solid state depends on the properties of solution fluidity. Water vapor permeability is the most studied characteristic of food films [11]. Mechanical, barrier properties, resistance of many food films to the penetration of gas or dissolved substances are largely dependent on the environmental conditions, such as relative humidity and temperature. Given this, scientists have thoroughly investigated the isotherms of sorption (adsorption and desorption) of these films [12].

Additional components in the composition of film-forming coatings are plasticizers, which improve mechanical properties and water resistance of materials: food acids, mono-, di-, oligo-sugars, polyalcohols, lipids [13].

Plasticizers are small, non-volatile molecules with a low molecular weight that can be added to films to increase elasticity and reduce friability [14]. These molecules function to reduce the intramolecular efforts along the polymer chain, which makes it possible to improve mobility and elasticity of the chain. It is also known that they decrease the temperature of vitrification of materials [15]. Plasticizers can also exert a certain negative impact on food films. This includes the enhancement of permeability for gas, solutions, and water vapor, as well as reduction in the adhesion of the film. It is important to note that above a certain concentration the plasticizer will not be compatible with a biopolymer, and there can occur a phase separation [16].

The study into influence of different plasticizers on the mechanical properties of dried biopolymeric films based on proteins of different origin is reported in paper [17]. It was found that the films that contain a plasticizer have a lower tensile strength than those that do not contain it. The authors also obtained results on a significant increase in the elongation of films when adding different plasticizers. Similar trends were observed when adding different plasticizers to "dry" gelatinous, gellan, gluten coatings [18].

By analyzing the scientific literature, we can conclude about the lack of information on the use of plasticizers of different origin to provide and control the desired characteristics of a film-forming coating based on sodium alginate and carboxymethyl cellulose (CMC).

Thus, it is required to conduct experimental research into the use of plasticizers for a film-forming coating based on sodium alginate and carboxymethyl cellulose in order to prolong duration period in the storage of chilled meat. 


\section{The aim and objectives of the study}

The aim of present study is to determine the effect of plasticizers of different origin on a change in the qualitative indicators of the film-forming coating based on sodium alginate and carboxymethyl cellulose (CMC), designed in advance.

To accomplish the aim, the following tasks have been set:

- to explore rheological properties, specifically viscosity, of solution of the film-forming coating depending on the applied plasticizer (glycerin, propylene glycol, sorbitol);

- to establish changes in the mechanical characteristics (tensile strength, relative elongation, water vapor permeability, puncture strength) of a film-forming coating depending on the utilized plasticizer.

\section{Materials and methods used in the study of qualitative indicators of film-forming coatings}

We used the following materials in the study:

$$
\begin{aligned}
& \text { - water (GOST 2874-82); } \\
& \text { - carboxymethyl cellulose (GOST 33310- }
\end{aligned}
$$
2015);

- sodium alginate (GOST 33310-2015);

- polyethylene glycol (GOST 8433-81);

- sorbitol (GOST P 53904-2010);

- glycerin (GOST 6824-96).

All the raw materials, employed in the conducted study, met acting standards in Ukraine in terms of quality and safety; their application is allowed by the Ministry of Health of Ukraine.

The technology for obtaining a film-forming coating implies the following stages.

At the first stage of fabrication of a film-forming coating, we agitate water and a plasticizer for $15 \mathrm{~s}$ so that the molecules of glycerin are distributed uniformly in the solvent.

At the second stage, we prepare dry ingredients; first they are weighed, then they are stirred. This operation is necessary so that when polysaccharides dissolve in water, better bonds are created and less water is separated.

At the third stage, the actual dissolution of polysaccharides occurs in the solvent at $t=18-22^{\circ} \mathrm{C}$; the temperature is predetermined by the fact that the selected polysaccharides dissolve in cold water.

The next operation, agitation, is necessary for the complete dissolution of polysaccharides, water binding, and uniform distribution of the molecules of polysaccharides throughout the volume of the resulting gel. The time required for complete dissolution of polysaccharides is 30 minutes.

At the fifth stage of technological operations, we carry out the process of degassing. The specified operation occurs in a vacuum installation at $t=18-22{ }^{\circ} \mathrm{C}$. This operation is required for the complete removal of bubbles or dissolved air from a solution of film-forming surfaces, which in turn leads to an increase in the mechanical indicators of the obtained films.

The next operation, aging, that lasts for $24 \mathrm{~h}$, is necessary to strengthen the structure of the gel.
The final stage is the application of coating on a special substrate made of plastic and its drying at $t=18-22{ }^{\circ} \mathrm{C}$ for 24 hours.

Procedure for determining the indicators of properties of the samples is given in detail in paper [19].

\section{Results of research into qualitative characteristics of film-forming coatings}

We prepared the following solutions of film-forming coatings for the study:

1) sodium alginate $+\mathrm{CMC}$;

2) sodium alginate $+\mathrm{CMC}+$ sorbitol;

3) sodium alginate $+\mathrm{CMC}+$ polypropylene glycol;

4) sodium alginate $+\mathrm{CMC}+$ glycerin.

The rheological properties of film-forming mixtures in the highest degree are characterized by such an indicator as viscosity, which directly affects the structural, mechanical, and barrier properties of coatings. The curves of steady flows of the film-forming solutions are shown in Fig. 1.

Fig. 1. Viscosity as a function of shear rate of hydrocolloid solutions: - sodium alginate + CMC; 2 - sodium alginate + CMC + sorbitol, 3 - sodium alginate $+\mathrm{CMC}+$ polypropylene glycol, $4-$ sodium alginate $+\mathrm{CMC}+$ glycerin

Note that all experiments on the measurement of viscosity of solutions of the film-forming coatings were conducted at the same temperature $\left(18{ }^{\circ} \mathrm{C}\right)$. In addition, viscosity of a film-forming solution is important when applying it to the product. The viscosity must be high enough to make the solution stick to the surface of meat, but not too high, because it would be difficult to apply a thin layer on the product.

Research into mechanical and physical indicators of the film.

Verification of mechanical indicators of film-forming coatings was performed at the universal test tool "Instron Universal Testing Instrument" (model 8802), in line with the standard ASTM D882-83.

Test samples were of length $217-255 \mathrm{~mm}$ and width $23 \mathrm{~mm}$. Data on the module of elasticity at stretching, stress at tearing and deformation at tearing, stress at elongation, stress at elongation for the limit of yield and deformation at elongation for the limit of yield, were collected and acquired directly from a computer. We have repeated not less than five times each of the test of samples of film-forming coatings. Results of the study are given in Table 1. 
Table 1 We studied vapor permeability to assess the Mechanical properties of film coatings acquired at Instron $(n=5, p \leq 0.05)$

\begin{tabular}{|c|c|c|c|c|c|c|c|}
\hline \multicolumn{4}{|c|}{ Sample characteristic } & \multicolumn{4}{|c|}{ Test results } \\
\hline $\begin{array}{l}\text { No. of } \\
\text { entry }\end{array}$ & $\begin{array}{c}\text { Film } \\
\text { width, } \\
\text { mm }\end{array}$ & $\begin{array}{c}\text { Film } \\
\text { thick- } \\
\text { ness, mm }\end{array}$ & $\begin{array}{c}\text { Film } \\
\text { length, } \\
\text { mm }\end{array}$ & $\begin{array}{c}\text { Maximal } \\
\text { effort at } \\
\text { breaking } \\
P_{\max }, \mathrm{N}\end{array}$ & $\begin{array}{c}\text { Tempo- } \\
\text { rary re- } \\
\text { sistance, } \\
\mathrm{MPa} \\
\end{array}$ & $\begin{array}{c}\text { Young } \\
\text { modulus, } \\
\text { MPa }\end{array}$ & $\begin{array}{c}\text { Relative } \\
\text { elongation } \\
\text { at tearing, } \\
\%\end{array}$ \\
\hline 1 & \multirow{4}{*}{23} & 0.08 & \multirow{4}{*}{250} & 30.24 & 10.34 & 557.98 & 10.20 \\
\hline 2 & & 0.07 & & 18.27 & 11.35 & 951.49 & 8.18 \\
\hline 3 & & 0.10 & & 33.92 & 14.74 & 721.22 & 7.50 \\
\hline 4 & & 0.10 & & 34.19 & 15.10 & 898.50 & 12.60 \\
\hline
\end{tabular}
effectiveness of the barrier characteristics of films. One of the main properties of film-forming coatings is the capability to retain moisture, thereby preventing the loss of mass of meat during storage.

At the same time, vapor permeability was determined because preserving a natural color of meat requires the access of oxygen so that the product does not lose its natural properties during storage while not absorbing odor from the environment. Research results are given in Table 2.

By analyzing the results in Table 1 , one can conclude that the film-forming coating based on sodium alginate $+\mathrm{CMC}+$ glycerin showed the highest results for such indicators: $P_{\max }=34,19 \mathrm{~N}$, temporary resistance, which is equal to $15.10 \mathrm{MPa}$, and relative elongation $-12.60 \%$. In turn, based on the Young modulus, the best result was demonstrated by the coating sodium alginate $+\mathrm{CMC}+$ sorbitol (951.49 $\mathrm{MPa})$, although it should be noted that the coating based on sodium alginate $+\mathrm{CMC}+$ glycerin had a not much lower indicator (898.98 $\mathrm{MPa})$. By summing up the results of physical indicators, it can be argued that the best characteristics are demonstrated by the coating based on sodium alginate+

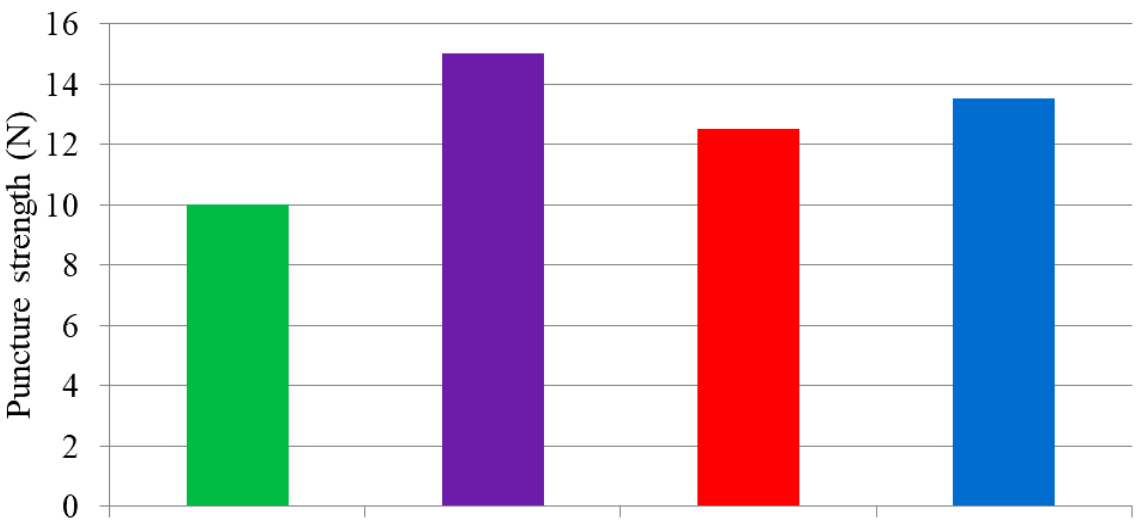

Alginate $+\mathrm{CMC}$ Alginate $+\mathrm{CMC}+$ Alginate $+\mathrm{CMC}+$ Alginate $+\mathrm{CMC}+$ glycerin propylene glycol sorbitol

Fig. 3. Puncture strength of the film-forming coating based on sodium alginate and carboxymethyl cellulose with different plasticizers

$\mathrm{CMC}+$ glycerin.

\section{$\sigma, \mathrm{MPa}$}

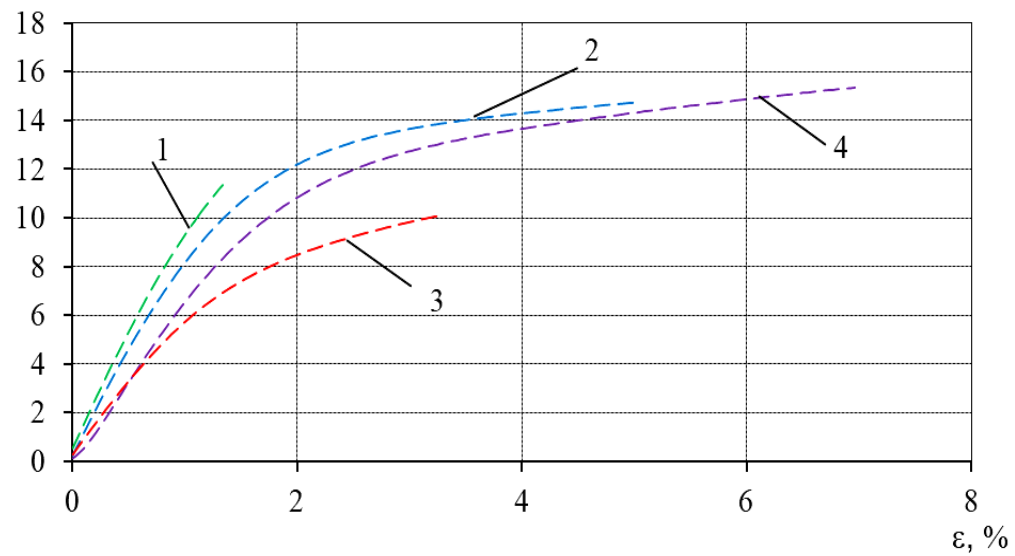

Fig. 2. Stress-deformation dependence curves for food films: 1 - sodium alginate+CMC; 2 - sodium alginate+CMC+sorbitol; 3 - sodium alginate $+\mathrm{CMC}+$ polypropylene glycol, 4 - sodium alginate+CMC+glycerin

Fig. 2 shows general information on the mechanical properties of food films, giving some of these characteristics.

In addition to tensile strength, we studied in the examined film-forming coatings the puncture strength because meat cuts have a complex geometrical shape and bone inclusions. The results obtained for the puncture strength are shown in Fig. 3
Table 2

Vapor permeability indicators for film-forming coatings $(n=5, p \leq 0.05)$

\begin{tabular}{|c|c|c|c|c|}
\hline \multicolumn{5}{|c|}{ Integrated film-forming coatings } \\
\hline No./Indicator & 1 & 2 & 3 & 4 \\
\hline $\begin{array}{c}\text { Vapor } \\
\text { permeability, } \\
\mathrm{mg} /\left(\mathrm{m}^{2} \cdot \mathrm{h} \cdot \mathrm{Pa}\right)\end{array}$ & 2,360 & 2,980 & 2,720 & 2,450 \\
\hline
\end{tabular}

Note that the research into mechanical, rheological, and physical characteristics of the film-forming coating was performed at a stable temperature and humidity of the environment.

\section{Discussion of results of research into effect of plasticizers on the mechanical, rheological, and physical indicators of film-forming} coatings

The dissolution and dispersion of hydrocolloids are affected by the size and shape of particles, specific surface, granulometric composition. Of great importance is the technique for preparing a solution (dispersion): the intensity and time of agitation, temperature, $\mathrm{pH}$ index, the presence of electrolytes, etc.

Viscosity plays an important role in applying a coating on meat using the spraying method, since viscosity of the solution will not change when it passes through the nozzles.

The results shown in Fig. 1 demonstrate that viscosity of the film-forming coating without adding a plasticizer has the 
largest value compared to other solutions. The film-forming coating based on sodium alginate $+\mathrm{CMC}+$ glycerin has the lowest value of viscosity; in addition, it has the closest value to a Newtonian fluid behavior.

It is known that the polar water molecules are arranged in this case around the polar groups of a hydrocolloid. Due to solvation, which is often accompanied by the deployment of a molecule, water molecules mobility is limited, and the viscosity of the solution increases.

The macromolecules, which at swelling partially or completely pass into the elongated state, increase viscosity in the greatest degree because the hydrodynamical resistance of long elongated polymer chains is the largest. The exponential law as a model is characteristic of polymers. This model shows that the polymer molecules are oriented in the direction of the flow, so it can explain why viscosity decreases with increasing shear rate.

An increase in the degree of branching of the molecule of a hydrocolloid leads to a decrease in viscosity when the arrangement of side chains prevents binding the molecules of water. If the polar and non-polar groups reside mostly at the ends of the chain, it contributes to binding the water and to an increase in viscosity. The macromolecules with a high degree of branching can attain high viscosity only in concentrated solutions.

Mechanical strength of the formed films is in greater extent due to the fact that both alginate and carboxymethyl cellulose are the hydrocolloids with a non-branched structure, which are characterized by a more robust structure of gels and a greater viscosity of solutions. Partial association of molecules of alginate and carboxymethyl cellulose predetermines the uniformity of the structure.

The association of molecules and colloidal particles occurs due to the electrostatic interaction between charged groups with high electron density, by the formation of the so-called "chemical bridges" between molecules, as well as due to the mechanical adhesion of molecules [20].

To a certain degree, mechanical strength is due to the capability of sodium alginate to form solid gels at low temperatures. This is important under conditions of processing and storage of meat.

Results of the study, given in Table 1, show that the addition of plasticizers led to an increase in the elasticity of the film; at the same time, however, we observed a slight increase in strength. This is probably due to a decrease in the friability of films, as well as the formation of bonds between molecules of alginate, carboxymethyl cellulose and a plasticizer at the expense of interaction with hydroxyl groups.

Indicators of the tensile strength in our study (Table 1) were lower than some of the values described in the literature for "dry" alginate films. It was reported that the dried alginate films demonstrated a tensile strength of 85.9, 64.7, and 24.1 MPa. In addition, films in this work were thinner than the films in another paper $(0.07-0.1 \mathrm{~mm}$ versus $0.11-0.13 \mathrm{~mm})$. The values for the elongation at break in this study (Table 1) were slightly higher than those reported for certain "dry" alginate films [7].

The results obtained (Fig. 2) indicate that the differences in mechanical properties of the integrated film-forming coating depends on the chosen plasticizer. Based on these charts, it was established that the integrated film-forming coatings with the addition of a plasticizer had a higher yield limit, so they were stronger than the integrated film-forming coatings without adding a plasticizer. On the other hand, the values of deformation for film-forming coatings without the addition of a plasticizer were higher than the integrated film-forming coatingd with the addition of a plasticizer, so they were more elastic.

With increasing plastic deformation, the tensile strength decreases due to interaction at the molecular level.

Fig. 2 shows that at film stretching, an increase in the plastic deformation leads to an increase in tensile strength. This is a simple mechanical dependence without any interaction at the molecular level.

The results shown in Fig. 3 demonstrate that adding a plasticizer to the mixture of hydrocolloids increases the puncture strength. The highest values were demonstrated by the mixture of a film-forming coating based on sodium alginate, carboxymethyl cellulose, and glycerin.

The differences between the values of vapor permeability, which are given in Table 2, for the integrated film-forming coatings with or without the addition of a plasticizer may be due to the porous structure of films.

Water transport can occur by the diffusion and through the mechanism of dissolution, as a result of migration from the openings in films.

Water has high solubility and possesses properties of cluster formation in a polymer with a tendency towards the plasticization of a polymer matrix. Natural polymers are characterized by a significant clusterization of water and the plasticization of a matrix [21].

The study into physical properties of the developed film-forming coatings based on hydrocolloids revealed that coatings with a plasticizer demonstrate a larger vapor permeability

The reason is probably the hydrophilicity (high level of hydrophilicity increases vapor permeability) and, possibly, a different crystalline structure of polymers. The transport of water vapor mass into a semi-crystalline polymer primarily depends on the amorphous phase because the crystalline phase is typically non-permeable [22]. High crystalline structure can provide for a denser and more compact structure that contains less free volume for the migration of water molecules.

Direct investigation of the relationship between polar groups and solubility does not seem possible because of the complexity of interactions and actual difficulties in assessing such factors as the availability of polar groups, relative strength of the interaction water-water in comparison with water-polymer bonds and the size and shape of crystals and the degree of crystallinity of a polymer matrix, which affect the degree of permeability of polymers for water vapor.

Thus, it is established that the film-forming coatings made from sodium alginate + CMC with glycerin have better durability, greater elasticity and possess the best indicators of vapor permeability. Given the results obtained, the further research may explore, as a protective film-forming coating for chilled meat, the coating based on sodium alginate $+\mathrm{CMC}$ with glycerin.

\section{Conclusions}

1. The result of measuring the viscosity indicates that solutions that form films demonstrate a non-Newtonian behavior, that is, pseudo plasticity due to the reduced viscosity with increasing shear rate. 
2. It was established that vapor permeability increases with the addition of plasticizers; a film-forming coating without a plasticizer has a vapor permeability value of $2,360 \mathrm{mg} /\left(\mathrm{m}^{2} \cdot \mathrm{h} \cdot \mathrm{Pa}\right)$; adding sorbitol raises this indicator to $2,980 \mathrm{mg} /\left(\mathrm{m}^{2} \cdot \mathrm{h} \cdot \mathrm{Pa}\right)$. It should be noted that the film based on alginate $+\mathrm{CMC}+$ glycerin has a vapor permeability value of $2,450 \mathrm{mg} /\left(\mathrm{m}^{2} \cdot \mathrm{h} \cdot \mathrm{Pa}\right)$, which is not significantly different from the film without a plasticizer.

Mechanical experiments have shown that the film-forming coating based on sodium alginate $+\mathrm{CMC}+$ glycerin demonstrated the highest results for such indicators as $P_{\max }=$
$=34.19 \mathrm{~N}$, temporary resistance, which is equal to $15.10 \mathrm{MPa}$, and a relative elongation of $12.60 \%$, puncture strength is $15 \mathrm{~N}$. In turn, the best result for the Young modulus was demonstrated by the coating based on sodium alginate+ $\mathrm{CMC}+$ sorbitol $(951.49 \mathrm{MPa})$, although it should be noted that the coating based on sodium alginate $+\mathrm{CMC}+$ glycerin had a not much lower rate $(898.98 \mathrm{MPa})$.

Thus, it is established that the film-forming coatings made from sodium alginate $+\mathrm{CMC}$ with glycerin are of the greatest interest for further research that would involve the use of coatings directly on meat.

\section{References}

1. Fillips G. O., Vil'yams P. A. Spravochnik po gidrokolloidam / A. A. Kochetkova (Ed.). Sankt-Peterburg: GIORD, 2006. 535 p.

2. Ščetar M., Kurek M., Galic K. Trends in meat and meat products packaging // Food Sci. Technol. 2010. Vol. 2, Issue 1. P. 32-48.

3. Vinnikova L. H., Kyshenia A. V. Biozakhysne pokryttia dlia podovzhennia terminu zberihannia miasa // Współpraca Europejska. 2016. Issue 1 (8). P. $97-107$.

4. Madhumita R., Ramalingam C. Bioedible coating of meat using garlic, cinnamon and turmeric // European Journal of Experimental Biology. 2012. Vol. 2, Issue 5. P. 1439-1443.

5. Effect of Soy Protein Isolate Coating on Meat Quality of Pork Fresh Cut during Refrigerated Storage / Shon J.-H., Kim J.-H., Eo J.-H., Choi Y.-H. // Journal of Applied Biological Chemistry. 2012. Vol. 55, Issue 1. P. 27-34. doi: 10.3839/jabc.2011.055

6. Application of edible coating for improving meat quality / Khan M. I., Adrees M. N., Tariq M. R., Sohaib M. // Pacing. Journal Food Science. 2013. Vol. 23, Issue 2. P. 71-79.

7. Li J.-M., Nie S.-P. The functional and nutritional aspects of hydrocolloids in foods // Food Hydrocolloids. 2016. Vol. 53. P. 46-61. doi: 10.1016/j.foodhyd.2015.01.035

8. Gohil R. M. Synergistic blends of natural polymers, pectin and sodium alginate // Journal of Applied Polymer Science. 2010. Vol. 120, Issue 4. P. 2324-2336. doi: 10.1002/app.33422

9. Composite Edible Films Based on Hydroxypropyl Methylcellulose Reinforced with Microcrystalline Cellulose Nanoparticles / Bilbao-Sáinz C., Avena-Bustillos R. J., Wood D. F., Williams T. G., McHugh T. H. // Journal of Agricultural and Food Chemistry. 2010. Vol. 58, Issue 6. P. 3753-3760. doi: 10.1021/jf9033128

10. New edible coatings composed of galactomannans and collagen blends to improve the postharvest quality of fruits - Influence on fruits gas transfer rate / Lima Á. M., Cerqueira M. A., Souza B. W. S., Santos E. C. M., Teixeira J. A., Moreira R. A., Vicente A. A. // Journal of Food Engineering. 2010. Vol. 97, Issue 1. P. 101-109. doi: 10.1016/j.jfoodeng.2009.09.021

11. Jirukkakul N. A study of Mu Yor sausage wraps using chitosan films incorporating garlic oil, lemon grass oil and galangal oil // International Food Research Journal. 2013. Vol. 20, Issue 3. P. 1199-1204.

12. Lima A. M. F., Soldi V., Borsali R. Dynamic light scattering and viscosimetry of aqueous solutions of pectin, sodium alginate and their mixtures: effects of added salt, concentration, counterions, temperature and chelating agent // Journal of the Brazilian Chemical Society. 2009. Vol. 20, Issue 9. P. 1705-1714. doi: 10.1590/s0103-50532009000900020

13. Tang X., Alavi S., Herald T. J. Effects of plasticizers on the structure and properties of starch-clay nanocomposite films // Carbohydrate Polymers. 2008. Vol. 74, Issue 3. P. 552-558. doi: 10.1016/j.carbpol.2008.04.022

14. Atarés L., Bonilla J., Chiralt A. Characterization of sodium caseinate-based edible films incorporated with cinnamon or ginger essential oils // Journal of Food Engineering. 2010. Vol. 100, Issue 4. P. 678-687. doi: 10.1016/j.jfoodeng.2010.05.018

15. Oms-Oliu G., Soliva-Fortuny R., Martín-Belloso O. Using polysaccharide-based edible coatings to enhance quality and antioxidant properties of fresh-cut melon // LWT - Food Science and Technology. 2008. Vol. 41, Issue 10. P. 1862-1870. doi: 10.1016/ j.lwt.2008.01.007

16. Chen J. L., Zhao Y. Effect of Molecular Weight, Acid, and Plasticizer on the Physicochemical and Antibacterial Properties of $\beta$-Chitosan Based Films // Journal of Food Science. 2012. Vol. 77, Issue 5. P. E127-E136. doi: 10.1111/j.1750-3841.2012.02686.x

17. Evtushenko M. V., Bredihina O. V. Hranenie morozhenoy produkcii iz ob'ektov vodnyh biologicheskih resursov s ispol'zovaniem plenochnyh modificirovannyh pokrytiy // Rybnoe hozyaystvo. 2013. Issue 3. P. 103-104.

18. Snezhko A. G., Gubanova M. I., Semenov G. V. Perspektivnye napravleniya primeneniya pokrytiy iz prirodnyh polimerov // Myasnaya industriya. 2011. Issue 8. P. 43-46.

19. Investigation of the role of plasticizers in film-forming coats for protecting cooled meat / Kyshenia A., Vinnikova L., Volovik T., Kotliar Y., Garbazhiy K. // EUREKA: Life Sciences. 2018. Issue 2. P. 27-34. doi: 10.21303/2504-5695.2018.00594

20. Pestyna A. A. Perspektyvy vykorystannia system na osnovi alhinatu natriyu ta pektynu v tekhnolohiyi kharchovykh produktiv // Materialy V Mizhnarodnoi konferentsiyi «Nyzkotemperaturni ta kharchovi tekhnolohiyi u XXI stolitti». 2011. P. 255-257.

21. Kambulova Yu. V., Sokolovska I. O. Doslidzhennia reolohichnykh vlastyvostei rozchyniv pektyniv, alhinatu natriyu ta yikh kompleksiv // Kharchova nauka i tekhnolohiya. 2014. Issue 1 (26). P. 68-73.

22. Edible films from Polysaccharides / Dhanapal A., Sasikala P., Rajamani L., Kavitha V., Yazhini G., Banu M. S. // Food science and Quality Management. 2012. Vol. 3. P. 9-17. 